\title{
The Value of Liberal Theories of Citizenship Education: A Response to Merry
}

\author{
Anniina Leiviskä (University of Helsinki)
}

\begin{abstract}
:
In this brief response, I defend liberal theories of citizenship education - especially those based on John Rawls' political liberalism - against Merry's critique, and I also attempt to shed light on what I think is their enduring significance in view of today's political climate.
\end{abstract}

Keywords:

reply

In his article "Citizenship, Structural Inequality and The Political Elite", Michael Merry criticizes liberal theories of citizenship education in relation to the political landscape of contemporary European democracies. His critique is based on two primary arguments: first, according to Merry, these theories are unable to provide normative guidance for actual educational practices because of the immense dissonance between their idealized accounts of education and the political reality in which citizenship education policies are implemented. Merry's second, interrelated argument is that instead of providing means for reasoned criticality, political dissent, and resistance, citizenship education serves the reproduction of current political arrangements established by academic and political elites. Accordingly, Merry claims that citizenship education is utilized to marginalize and exclude those members of the society whose values, ethnicities or cultural backgrounds are not included in the predominant definitions of 'good citizenship'.

In this brief response, I defend liberal theories of citizenship education - especially those based on John Rawls' political liberalism - against Merry's critique, and I also attempt to shed light on what I think is their enduring significance in view of today's political climate. Although Merry's critique is not explicitly directed against Rawls, he employs Michael Clayton's work, which is primarily rooted in Rawls's philosophy, as an example of the problematic, idealizing theories of citizenship education mentioned above. Furthermore, Merry's critique also follows the line of argumentation typically raised by representatives of the so-called non-ideal theory against Rawls' work. Although there is much elaborate research on the ideal versus non-ideal theory debate in both political philosophy and philosophy of education, I will not use much space for summarizing this discussion. Instead, I will focus on arguments that in my view are beneficial for clarifying the value of liberal theories of citizenship education in the context of contemporary European democracies.

Let us first consider Merry's argument concerning the inability of liberal theories of citizenship education to provide guidance for action due to their alleged ideality. It must first be noted that most liberal theories of citizenship education are not strictly ideal but they rather attempt to provide principles and criteria for regulating the operations of actual educational institutions and practices. Accordingly, these theories usually regard the questions of educational justice and citizenship education as inherently practical ones, which means that these questions only arise in the presence of certain 'social facts' - moderate scarcity, economic and social inequality, differences in talent and ability between individuals, and so on - and thus these theories include a variety of factual considerations about human agents, liberal democratic societies, and educational institutions. On the other hand, as Merry correctly indicates, liberal theories of citizenship education also typically involve idealizing assumptions that abstract from social and political reality: they frequently begin with ideal educational aims such as the civic virtue of reasonableness or autonomy and then work from these aims toward more concrete educational practices. Moreover, these theories typically assume what Rawls (1999, p. 125) refers to as "strict compliance", which in this context means that educational institutions and agents are expected to function in accordance with certain liberal democratic principles, and thus to create a space for educational practices and settings that are appropriate for pursuing the aforementioned educational aims. 
Merry is correct in arguing that by making idealizing assumptions liberal theories of citizenship education reduce the possibilities of their direct applicability to actual educational institutions and practices. Consequently, these theories - at least to a certain extent - jeopardize their effectiveness. Hence, the important question is why theories of citizenship education should start from idealizations in the first place? Elizabeth Edenberg (2018) partially responds to this question in her contribution to the first issue of On Education: criticizing current practices as unjust, oppressive or exclusive relies either explicitly or implicitly on some normative ideal, and thus a clear articulation of this ideal is important for justifying the critique of actual educational institutions and practices. Furthermore, even if we did not need an exact view of an ideally just educational system, as Harry Brighouse (2015) indicates, we still need a measure to compare the quality of different states of affairs, just as we need a notion of height to compare the relative height of mountains. Accordingly, we cannot really recognize educational injustices or suggest reforms to correct them unless we have some kind of a standard of justice for assessing prevailing institutions and practices. Theories in political philosophy (such as Rawls' justice as fairness and his political liberalism) represent attempts to justify these standards and, in my view, philosophers of education need these theories for constructing and legitimizing their views on educational justice and political education.

In fact, Merry's critique is not primarily directed to the attempt to construct educational ideals per se. Instead, its main target is the assumed compliance of actual educational institutions and agents to these ideals. As indicated above, Merry argues that citizenship education, as it is carried out in contemporary European societies, does not operate in accordance with liberal democratic values and principles but it rather serves to reproduce the current political arrangements by cultivating dispositions required for obeying existing laws and social norms. But should partial (or non-)compliance of actual educational institutions and practices to liberal democratic principles result in surrendering the assumption of full compliance altogether? Merry himself admits that empirical states of affairs do not exclude possibilities of normative argument. It also seems to me that in the attempt to find the fair way of arranging educational institutions and practices, our theorizing should not in the first instance be affected by thoughts of agents and institutions not being able to act according to what justice demands. As Laura Valentini (2009) and Jacob Levy (2016) point out, if motivational and behavioral deficiencies of agents were taken into account from the start in the elaboration of a normative theory, the whole endeavor would be plagued with indeterminacy, and such theory might also result in lacking the necessary critical distance to assess the prevailing political and institutional arrangements. Justice demands analysis in terms of full compliance, even if partial or non- compliance of actors and institutions is taken into consideration later (Levy, 2016).

While the arguments above might already count as sufficient reasons for sustaining idealization as a part of educational theorizing, in the context of contemporary theories of citizenship education, pluralism and the issue of legitimacy of political use of power that arises with it provides one more highly important reason. As Rawls (2005) explains in Political Liberalism, in political philosophy idealization or abstraction is not conducted just for the sake of it but we rather turn to idealization and philosophical justification when our shared political understandings are broken down and we face severe conflicts in values. Political philosophy thus attempts to look beyond differences and outline principles that we all can share and, indeed, should share simply because sufficient compliance to these principles is a precondition for the ability to sustain a stable and just constitutional democracy over time. Ironically, it is thus precisely through idealization that political liberalism and the associated theories of citizenship education aim to prevent the organization of democratic institutions and practices in a manner that only serves the interests of one particular social class or political group. In other words, through idealization, political liberalism strives for impartiality and seeks to ensure that the interests and rights of all citizens are served equally. In this sense, it is somewhat paradoxical that the critics of liberal theories of citizenship education, Merry included, associate idealization with unjust social and political exclusion. Evidently, sustaining a just and stable constitutional democracy over time requires that there are certain limits to democratic participation which cannot be surpassed without jeopardizing such fundamental democratic values as equality, liberty, and inclusion. For instance, fundamentalisms of different kinds cannot be unproblematically included in the democratic regime because their inclusion would potentially result in the gradual erosion of the aforementioned democratic core values. "There can be no inclusion without exclusion", as Habermas (2006, p. 197) points out.

This takes us to Merry's second argument, which bears a certain resemblance to that represented by Charles Mills (2005) in his famous article "Ideal Theory as Ideology". The most important message of Mill's article could perhaps be summarized as follows: the depiction of ideal theory as an idealized abstraction from real states of affairs - real democratic processes, real institutional settings, and so forth - makes it difficult to identify those processes and states of affairs as sources of injustice. For instance, when political theory such as Rawls' political liberalism draws principles of justice from the existing political culture and presents them in an idealized form as 'rational' or 'moral', it serves to legitimize - or so the argument goes - the existing institutions and thus it conceals their participation in creating and sustaining injustice. The problem for Mills, 
and also for many representatives of the so-called radical theory of democracy such as Chantal Mouffe and Jacques Rancière, is that ideal theory masks as 'rational' values and principles that actually result from effective use of political power.

Let us consider this argument from the point of view of the principle of reasonableness, which in Rawls' political liberalism sets the limits for democratic participation, and which is also one of the primary aims of citizenship education in the Rawlsian framework. For Rawls the primary feature of reasonableness is reciprocity, which refers to citizens' willingness to propose standards and rules of fair co-operation which they believe all other reasonable citizens as free and equal could accept and abide by. Consequently, reasonable citizens and doctrines will also accept the constitutional democratic regime and its companion idea of legitimate law (Rawls, 2005). Moreover, reasonableness requires tolerance in the form of "burdens of judgment" (Rawls, 2005, p. 54) which means, simply put, that reasonable citizens acknowledge that complex questions of the good life can be resolved in many, equally plausible ways from the perspective of different comprehensive doctrines. Accordingly, citizens recognize the right of other citizens to organize their life according to whichever reasonable doctrine they choose. Rawls believes that reasonableness (and the attendant political idea of constitutional neutrality) is a necessary criterion for legitimate use of political power in liberal democracies consisting of a plurality of different but irreconcilable comprehensive doctrines, because without such criterion political power might be used in ways that jeopardizes the basic rights and liberties of some citizens. The purpose of the principle of reasonableness is thus to protect the rights and liberties of all citizens and to prevent oppressive use of political power in societies where the fact of pluralism prevails.

If we consider reasonableness from the perspective of Merry's and Mills' arguments, the claim would be that this principle cannot be viewed as a rational criterion for democratic participation. Rather, in reality, it is something established and upheld by academic and political elites and thus it serves to secure the realization of their interests. Accordingly, the principle is utilized to oppress or exclude those members of the society who are not included in this particular definition of rationality and the ideal of citizenship associated with it. Evidently, all normative principles can be twisted and turned in political practices in such ways that they end up serving ideological aims - the history of humanity is full of examples of this. However, in the case of reasonableness, to utilize it in an oppressive or exclusive manner would evidently negate the whole content and purpose of the principle as its very function is to ensure that political power is not used in such ways. The Rawlsian principle only excludes those having "the zeal to embody the whole truth in politics" (Rawls, 2005, p. 442) as such "zeal" is incompatible with the fact of pluralism as well as the right of other citizens to live as they choose (within the limits of reasonableness). Thus, as Victoria Costa (2011) points out, Rawlsian reasonableness is evidently harmful to anti-democratic, intolerant and dogmatic doctrines but this should not be seen as something to be criticized but rather something in favour of the proposal. In fact, Rawlsian reasonableness is the very principle that can be utilized to criticize and condemn such exclusive, discriminatory, and racist political views and practices that Merry himself opposes in his essay. Most importantly, to give up the principle of reasonableness in democratic politics would mean making way to dogmatic, intolerant, and fundamentalist views the rise of which we are already witnessing in many European countries.

It can of course also be argued that the principle of reasonableness is so unrealistic that all attempts to apply it in actual democratic or educational practices are destined to fail, and thus the principle is simply futile. However, such argument disregards important aspects of the social and political reality in which we live because this reality, in my view, is not as deeply unreasonable as Merry's essay implies. I agree with Rupert Wegerif (2018) that some contemporary theories of citizenship education express a certain obliviousness for the work that has been done by democratic educators, politicians, policy makers and political activists to achieve where we are now. Ultimately, it is a grand achievement and a result of a long political struggle that many European societies today can be regarded as relatively stable liberal democracies where basic human rights and liberties are protected by constitution and law. And, at the same time, it is important to acknowledge that constitutional democracies of the kind we have now are historical peculiarities. As Wegerif (2018) illuminatingly cites John Gray, the assumption that everyone secretly wants freedom and equality is not well supported by the facts of human history, and thus such democratic values as equality, liberty, tolerance, and reciprocity - granted that there is still much work to be done in order to realize these values even in the most stable and relatively just democratic societies - are values to be fostered, cherished, and protected. Indeed, as Wegerif (2018) further indicates, to perceive every established political order as a 'police state' and every challenge to this order as a plea for democracy and equality is just as onesided and destructive as seeing the prevailing political order as fully just. Moreover, it is important to remember that it is precisely the view of the established political order as 'corrupted' and 'elitist' that right-wing populist parties have utilized to gain electoral support in many European countries, and it is this view that they have also used to justify their attempts to bring into democratic politics such discriminatory and racist views and demands that fail to meet the criterion of reasonableness and the virtues of reciprocity and tolerance inherent in it. 
Evidently, I am not denying that the prevailing political order and democratic institutions in contemporary liberal democracies in many ways also sustain and help to reproduce practices that create inequality and injustice. But despite of their obvious limitations and faults, these institutions are also designed and utilized to protect basic human rights and liberties in ways that prevent the most severe forms of injustice from taking place. Hence, the fact that Merry largely ignores in his essay is that these rights and liberties exist - even if they only exist partially and imperfectly - in liberal democracies primarily because of constitution, legislation and democratic institutions, and not in spite of them. Hence, what I see as the enduring task of political philosophy and philosophy of education is the immanent assessment, critique, and development of democratic institutions and practices, which aims at helping them to meet what justice demands.

Moreover, it must also be pointed out that citizenship education that is based on liberal democratic theories such as Rawls' political liberalism by no means only encourages obedience to existing laws and political arrangements. On the contrary, citizenship education that takes the message of Rawls' theories seriously should cultivate students' awareness of the importance of distinguishing between what is right and what is currently recognized by law. Accordingly, it should introduce to students relevant historical examples of how different laws have been protested against, how some laws have been demonstrated as illegitimate and repealed and how new laws promoting equality and justice among citizens have been introduced and established. Rawlsian citizenship education should also involve discussions on the legitimacy of civil disobedience and conscientious objection - that is, it should address issues and questions (which Rawls also discusses in great detail in his Theory of Justice) such as 'in what circumstances can civil disobedience be regarded as legitimate', 'is violent civil disobedience ever justifiable', and 'when conscientious objection might be acceptable'. Moreover, Rawlsian citizenship education should also incorporate relevant knowledge of non-governmental organizations and citizens' initiatives as important channels of political participation and influencing. As Rawls sees liberal democracies as self-correcting political arrangements that renew themselves and regain their legitimacy through public reasoning, citizenship education taking after Rawls should not rest content with teaching students to conform to the existing political order. Instead, it should provide students with the ability to participate in such public deliberation in which the legitimacy of laws and prevailing political institutions is continuously reassessed.

Hence, the primary value of liberal theories of citizenship education in the light of the political reality of contemporary European democracies is, first, that they outline and justify normative educational ideals, such as
Rawlsian reasonableness and fair equality of opportunity, without which we could not recognize or justifiably criticize the injustices that Merry describes in his contribution. After all, if European democracies are utilizing citizenship education to marginalize and stigmatize students with immigrant backgrounds, these societies are miserably failing what is demanded of them by the aforementioned principles. Secondly, to me it seems important that in these theories no strict opposition exists between the prevailing political institutions and arrangements and the political struggles for democracy, equality and justice. Accordingly, questions of equality and justice are seen as issues that can be addressed and perhaps even resolved within state-run educational systems, institutions, and practices. It would be a mistake to regard political or citizenship education as something that can only be fruitfully carried out outside the formal educational system; this would mean pushing the struggle for equality and justice to the margins of the society. To refer to Wegerif's (2018) insightful contribution once more, significant social and political change takes time, and therefore drawing the conclusion that fostering civic virtues is futile from the fact that these virtues are not immediately realized in the society means denying the possibility that citizenship education might have a more indirect impact the results of which will only materialize later.

I agree with Merry, however, that many liberal theories of citizenship education deserve to be criticized for being insufficient as far as the dimension of non-ideal theorizing is concerned. Namely, many of these theories tend to focus too much on the justification of educational principles and ideals while neglecting reflection on the concrete practices through which these principles and ideals are implemented in actual educational institutions. I thus side with Merry on the view that liberal theories of citizenship education should strive to take more extensively into account the different forms of structural injustice that prevent the proper implementation and realization of liberal democratic principles in educational institutions. It is evident that if the whole educational system is designed in a way that effectively prevents students with, for instance, immigrant and lower-class backgrounds from entering higher education or pursuing certain valued positions in the society, a broader educational reform might be required before citizenship education carried out within this system can have any real social or political impact.

I also share Merry's view that schools can only do so much - for instance, many recent studies indicate that such phenomena as the rise of anti-democratic attitudes, the increasing electoral support for right-wing populist parties, and general distrust in the workings of democracy are associated with citizens' experiences of economic and social insecurity brought forth by significant changes in the arrangements between the economy and society in 
European democracies after the so-called 'Eurocrisis' (see Salmela \& von Scheve, 2017). Moreover, these political tendencies have been further fueled by the recent massmigration and its social and political repercussions. Considering these findings, it would be naïve to think that fostering rational deliberation, reasoned dissent, tolerance, and mutual respect in schools alone would be enough to respond to the current 'crisis of democracy'. The international phenomena related to global economy, military conflicts, and so forth are difficult to predict, not to mention influence or control on a national level, and it thus seems evident that rehabilitating the European democratic culture requires more than local educational reforms.

However, I cannot endorse Merry's pessimism to the full extent, especially when it comes to the possibilities of state-run educational institutions to foster democratic citizenship, reduce social injustice, and promote equality among citizens. While state-run educational institutions evidently cannot be the only agents to carry out significant social and political change, Finland is a good example of a country where a state-run comprehensive school system has historically been one of the key institutions in enabling upward social mobility and increasing social and economic equality among citizens. Evidently the undesirable social and political phenomena that Merry associates with the state-run school system are now also starting to appear in Finland but to me the appropriate way to respond to these problems is not to hand over political or citizenship education to non-governmental organizations. At least from a Finnish perspective, Merry constructs a somewhat artificial juxtaposition between state-run educational institutions and informal or non-governmental forms of political education. Also, in the context of liberal (and deliberative) theories of democracy, both governmental and non-governmental organizations belong to the same public political culture, and thus they both should take responsibility for educating future citizens.

\section{References}

Brighouse, H. (2015). Nonideal theorizing in education. Educational Theory, 65(2), 215-231. https://doi.org/10.1111/edth.12108

Costa, V. (2011). Rawls, citizenship, and education. Routledge.

Edenberg, E. (2018). Cultivating reasonableness in future citizens. On Education. Journal for Research and Debate, 1(1). https://doi.org/10.17899/on_ed.2018.1.8

Habermas, J. (2006). Religious tolerance: The pacemaker for cultural rights. In L. Thomassen (Ed.) The Derrida-Habermas Reader (pp. 195-207). Edinburgh University Press.

Levy, J. (2016). There is no such thing as ideal theory. Social Philosophy \& Policy, 33(1-2), 312-333.

Mills, C. (2005). Ideal theory as ideology. Hypatia, 20(3), 165-183.

Rawls, J. (1999). A theory of justice. Revised edition. The Belknap Press of Harvard University Press.

Rawls, J. (2005). Political liberalism. Expanded edition. Columbia University Press.

Salmela, M., \& von Scheve, C. (2017). Emotional roots of right-wing political populism. Social Science Information, 56(4), 567-595. https://doi.org/10.1177/0539018417734419

Valentini, L. (2009). On the apparent paradox of ideal theory. Journal of Political Philosophy, 17(3), 332-355. https://doi.org/10.1111/j.1467-9760.2008.00317.x

Wegerif, R. (2018). New technology and the apparent failure of democracy: An educational response. On Education. Journal for Research and Debate, 1(1). https://doi.org/10.17899/on_ed.2018.1.7

\section{Recommended Citation}

Leiviskä, A. (2018). The value of liberal theories of citizenship education: A response to Merry. On Education. Journal for Research and Debate, 1(1). https://doi.org/10.17899/on_ed.2018.1.12

\section{About the Author}

PhD Anniina Leiviskä works as a postdoctoral researcher at the University of Helsinki, Faculty of Educational Sciences in Finland. Her major areas of research are theories of democracy and citizenship education. She is particularly interested in the topics of political legitimacy, educational justice, and inclusion and participation in the context of political education and 
democratic politics. Her current research project Democracy, Education and the Challenge of Inclusion: Reconstructing a Theory of Citizenship Education for Contemporary Democracies (2017-2020) is funded by the Academy of Finland. 